\title{
"Ceria"
}

Jurnal Program Studi Pendidikan Anak Usia Dini

ISSN 2301-9905

Volume 7, No. 2, Januari 2018

Fakultas Keguruan dan Ilmu Pendidikan - Universitas Muhammadiyah Tangerang

\section{Upaya Meningkatkan Konsep Bilangan Melalui Puzzle Angka Pada Anak Usia 4-6 Tahun}

\author{
Ari Prabawati Susanto ${ }^{1}$ Evy Fitria ${ }^{2}$ \\ 1,2Program Studi Pendidikan Guru Pendidikan Anak Usia Dini, Fakultas \\ Keguruan dan Ilmu Pendidikan, Universitas Muhammadiyah Tangerang \\ e-mail: ${ }^{1}$ arieprabawati@gmail.com, 2evifitria7@gmail.com
}

\begin{abstract}
ABSTRAK
Mengenal konsep bilangan anak usia 4-6 tahun di TK Sabela belum berkembang dengan optimal. Dari 10 anak di kelas, ada 7 anak yang mengenal konsep bilangan nya masih rendah. Subjek penelitian ini adalah anak didik kelompok A yang mengalami masalah mengenal konsep bilangan, seperti menyebutkan urutan bilangan, membedakan lambang bilangan, dan dalam menulis lambang bilangan. Hasil penelitian menunjukan bahwa terjadi peningkatan kemampuan mengenal konsep bilangan dengan bermain puzzle angka. Kemampuan mengenal konsep bilangan anak pada siklus I mencapai 30\%, pada siklus II meningkat mencapai $50 \%$ dan meningkat lebih baik lagi pada siklus III yaitu $100 \%$. Dengan demikian dapat disimpulkan bahwa variasi dalam pembelajaran memiliki peranan penting dalam meningkatkan kemampuan mengenal konsep bilangan melalui bermain puzzle angka. Dengan demikian terbukti bahwa penerapan melalui bermain puzzle angka dapat meningkatkan kemampuan mengenal konsep bilangan anak kelompok di TK Sabela Kec. Pasar Kemis Kab. Tangerang.
\end{abstract}

Kata Kunci : mengenal konsep bilangan, puzzle angka, anak usia 4-6 tahun

\section{Pengantar}

Pendidikan anak usia dini merupakan salah satu lembaga pendidikan prasekolah yang di harapkan dapat menjadi fasilitator bagi perkembangan anak. Pendidikan anak usia dini diselenggarakan dengan tujuan untuk memfasilitasi pertumbuhan dan perkembangan anak secara menyeluruh, karena usia dini merupakan fase yang fundamental dalam mempengaruhi perkembangan anak. Sesuai dengan karakteristik anak usia dini yang aktif, rasa ingin tahu yang tinggi, banyak bertanya, dan sering bereksplorasi dengan lingkungannya yang tercemin dalam kegiatan pembelajaran yang menyenangkan bagi anak. 
"Ceria”

Jurnal Program Studi Pendidikan Anak Usia Dini

Sementara itu pakar pendidikan dari Direktorat PPAUD (Pentingnya Pendidikan Anak Usia Dini) mengatakan pendidikan anak usia dini sangat penting karena membentuk moral, kognitif, dan psikomotor anak. Ke depan nanti anak usia dini tersebut akan mempunyai kreativitas, keterampilan dan kemampuan yang baik ketika berada pada pendidikan formal SD sampai pada perguruan tinggi. Oleh karena itu pendidikan anak usia dini perlu menyediakan berbagai kegiatan pembelajaran yang dapat memperkembangkan sebagai aspek perkembangan. Salah satu kegiatan pembelajaran untuk anak usia dini adalah mengembangkan kemampuan logika matematika.

Gardner mendefinisikan kecerdasan logika metematika sebagai kemampuan penalaran ilmiah. Perhitungan secara metematis, berpikir logis, penalaran indukif/deduktif dan ketajaman pola-pola abstrak secara hubunganhubungan. Dapat diartikan juga sebagai kemampuan menyelesaikan masalah yang berkaitan dengan kebutuhan matimatika sebagai solusinya untuk itu pembelajaran matimatika berkembang secara optimal (Fatimah, 2009, hal. 23).

Dalam pembelajaran matematika salah satunya terdapat konsep bilangan dengan mengenal konsep bilangan. Mengenal konsep bilangan merupakan awal pengenalan matematika kepada anak usia dini, karena menjadi dasar pembelajaran matematika selanjutnya. Mengenal konsep bilangan tercantum pada Peraturan Menteri (Permen) No. 58 tahun 2009. Sebagaimana anak usia 4-6 tahun, diharapkan dapat mengenal konsep bilangan 1-10. Pemahaman konsep bilangan pada anak usia dini biasanya dimulai dengan mengeksplorasi bendabenda konkret yang dapat dihitung dan diurutkan.

Seperti yang dijelaskan oleh Direktorat Pendidikan Anak Usia Dini (2010, hal. 3) bahwa mengenal konsep bilangan adalah suatu hal yang dasar dalam mengembangkan pengetahuan matematika, dalam kegiatan sehari-hari anak sering sekali melafalkan bilangan, seperti $1 \ldots 2 \ldots 3 \ldots 4 \ldots 5 \ldots$ dst. Hal tersebut adalah langkah awal dalam mengenal konsep bilangan. Dalam proses mengenal konsep bilangan, anak akan memulai mempelajari bagian dari konsep bilangan 
"Ceria"

Jurnal Program Studi Pendidikan Anak Usia Dini

selanjutnya yaitu menghitung, korenspondensi satu-satu, membandingkan, dan mengenal simbol angka. Dengan demikian mengenalkan konsep bilangan pada anak usia dini merupakan langkah awal yang harus diperkenalkan agar anak mampu mengembangkan pengetahuan matematikanya.

Dunia anak adalah dunia bermain. Bermain sambil belajar atau belajar seraya bermain, mengeksplorasi benda-benda yang ada disekitar anak merupakan kegiatan yang menyenangkan. Mengarahkan anak pada permainan yang menyenangkan dapat merangsang pertumbuhan otak dan fisiknya. Anak bermain secara spontan. Bermain merupakan kegiatan yang dilakukan anak secara spontan karena disenangi, dan seiring tanpa tujuan tertentu. Bagi anak, bermain merupakan suatu kegiatan yang sangat disenanginya secara spontan tanpa adanya tujuan (Montolalu, dkk, 2014, hal. 10)

Bermain puzzle sebenarnya bukan permainan yang baru, diantara permainan yang menyenangkan dan penuh tantangan adalah bermain puzzle. Semua puzzle bisa di pakai. Namun, untuk lebih menekankan pada kebiasaan membaca, menulis, dan berhitung, kita pilihkan permainan puzzle huruf atau angka. Hal ini berarti puzzle suatu kegiatan bermain yang memerlukan konsentrasi untuk menyusun kepingan-kepingan menjadi gambar yang utuh dengan tingkat kesulitan yang bertahap (Murtie, 2013, hal. 98).

Beberapa diantara permainan yang menyenanangkan dan penuh tantangan adalah bermain puzzle. Puzzle menurut Astuti (2016, hal. 52) dapat berupa gambar ataupun yang di buat dari potongan-potongan kecil gambar yang di gabungkan, dua jenis puzzle ciptaanya yaitu puzzles out of desigens and pattems (puzzle tanpa tekstur dan desain).

Dengan demikian, bermain puzzle angka dapat membantu meningkatkan kemampuan mengenal konsep bilangan anak. Melalui bermai puzzle angka anak dapat mengembangkan pengetahuan mengenal konsep bilangan. Puzzle angka merupakan bentuk permainan yang menantang daya kreatifitas dan ingatan anak usia dini lebih mendalam dikarenakan muncul nya motivasi untuk senantiasa 
"Ceria”

Jurnal Program Studi Pendidikan Anak Usia Dini

mencoba memecahkan masalah, namun tetap menyenangkan sebab bisa di ulangulang. Tantangan dalam permainan akan selalu memberikan efek ketagihan untuk selalu mencoba, mencoba terus mencoba hinga berhasil.

\section{Metode}

Metode penelitian yang digunakan dalam penelitian ini adalah Penelitian Tindakan Kelas (PTK), dengan subjek penelitian yaitu anak kelompok A (usia 4-6 tahun) di TK Sabela Kec. Pasar Kemis Kab. Tangerang. Menurut (Mulyasa, 2016, hal. 29) Penelitian Tindakan Kelas adalah penelitian tindakan yang dilakukan dengan tujuan untuk memperbaiki kualitas proses dan hasil belajar sekelompok peserta didik. Bentuk penelitian tindakan yang digunakan dalam penelitian ini adalah penelitian tindakan kolaboratif. Suhardjono (2015, hal. 78) menjelaskan bahwa pada PTK jenis tersebut terdapat kolaborasi atau kerja sama antara peneliti (dalam hal ini mahasiswa, atau dosen, atau peneliti yang lain) dengan praktisi, yakni guru yang akan melakukan proses pembelajaran di saat PTK berlangsung. Dalam penelitian ini kolaborasi dilakukan antara peneliti dan guru kelas, dimana peneliti bertindak sebagai observer dan guru bertindak sebagai pelaksana tindakan. Dalam Penelitian Tindakan Kelas ini, tindakan yang dilakukan adalah meningkatkan kemampuan mengenal konsep bilangan pada anak usia 4-6 tahun, dengan fokus pada aspek-aspek mengenal konsep bilangan antara lain yaitu menyebutkan urutan bilangan 1-10, Membilang (Mengenal konsep bilangan dengan benda-benda) 1-10, Merangkai puzzle himpunan 1-10, menulis konsep bilangan 1-10, Mencocokan bilangan dengan lambang bilangan 1-10, Mengurutkan bilangan dengan menggunakan puzzle angka 1-10, serta Membedakan dan membuat 2 kumpulan benda yang sama jumlahnya, yang tidak sama, lebih banyak dan lebih sedikit.

Desain penelitian yang digunakan adalah model Kemmis dan Taggart, yaitu dilakukan dalam tiga siklus dan empat tindakan/pertemuan pada setiap siklusnya. Tahapan dalam penelitian ini adalah perencanaan, pelaksanaan 
"Ceria"

Jurnal Program Studi Pendidikan Anak Usia Dini

tindakan, pengamatan dan refleksi. Instrumen yang digunakan dalam penelitian ini yaitu berupa lembar penilaian berupa daftar checklist, catatan wawancara, catatan lapangan serta dokumentasi. Teknik analisis data yang digunakan adalah berupa data kuantitatif dan data kualitatif.

\section{Hasil Dan Pembahasan}

Peningkatan mengenal konsep bilangan anak dalam penelitian ini dilakukan dengan bermain puzzle angka dalam tiga siklus, setiap siklus terdiri dari empat pertemuan. Mengenal konsep bilangan anak diukur berdasarkan tiga indikator yaitu menyebutkan urutan bilangan 1-10, Membilang (Mengenal konsep bilangan dengan benda-benda) 1-10, dan Merangkai puzzle himpunan 1-10.

Penerapan kegiatan mengenal konsep bilangan yang dilakukan peneliti menggunakan alat dan bahan serta membahas tema yang berbeda pada setiap siklus. Pada siklus I tema yang dibahas adalah diri ku dengan sub tema alat panca indera. Alat dan bahan yang digunakan adalah gambar panca indera, lembar kerja dan puzzle angka 1-5.

Hasil pengamatan pada siklus I peneliti mengamati bahwa anak yang sedang mengamati konsep bilangan masih mengalami kesulitan ketika untuk menjawab pertanyaan dari peneliti, anak masih ragu-ragu untuk menjawab karena lupa dengan urutan konsep bilangan karena masih belum banyak bilangan yang mereka ingat. 
"Ceria"

Jurnal Program Studi Pendidikan Anak Usia Dini

Tabel 1

Hasil Observasi Konsep Bilangan Anak Siklus I

\begin{tabular}{cccccccccccc}
\hline Nama & \multicolumn{1}{c}{ Indikator } & & & \multicolumn{2}{c}{ Jumlah } \\
\cline { 2 - 5 } & \multicolumn{1}{c}{1} & & 2 & & 3 & & & 4 & F & $\%$ \\
\hline ADL & 4 & 4 & 4 & 4 & 3 & 4 & 4 & 3 & 3 & 33 & $91 \%$ \\
AZA & 3 & 2 & 2 & 3 & 1 & 2 & 3 & 2 & 1 & 19 & $52 \%$ \\
BUL & 3 & 2 & 2 & 3 & 2 & 2 & 2 & 1 & 2 & 19 & $52 \%$ \\
FEB & 1 & 1 & 1 & 2 & 2 & 2 & 2 & 1 & 1 & 13 & $36 \%$ \\
KEY & 3 & 2 & 2 & 2 & 1 & 2 & 2 & 2 & 2 & 18 & $50 \%$ \\
LIK & 1 & 2 & 1 & 2 & 2 & 2 & 2 & 1 & 1 & 13 & $36 \%$ \\
MAR & 2 & 2 & 2 & 2 & 2 & 2 & 2 & 1 & 1 & 16 & $44 \%$ \\
NA & 2 & 1 & 2 & 2 & 2 & 2 & 2 & 2 & 1 & 16 & $44 \%$ \\
NAY & 4 & 4 & 4 & 4 & 3 & 3 & 3 & 3 & 4 & 32 & $88 \%$ \\
ZAK & 4 & 4 & 4 & 4 & 3 & 3 & 4 & 3 & 4 & 33 & $91 \%$ \\
\hline
\end{tabular}

Berdasarkan tabel 1 di atas diketahui bahwa kemampuan mengenal konsep bilangan pada siklus ini, terlihat bahwa kemampuan mengenal konsep bilangan anak telah meningkat dengan persentase peningkatan sebesar $30 \%$, yaitu dari 10 anak ada 3 anak yang skor kemampuan mengenal konsep bilangan telah mencapai indikator yang telah ditentukan.

Berdasarkan temuan tersebut, peneliti melakukan perbaikan pada siklus II agar hasil yang dicapai dapat lebih optimal. Peneliti menambahkan variasi puzzle angka dan bahan yang lebih luas untuk digunakan anak agar anak dapat mengenal konsep bilangan dan menyusun puzzle angka dengan mandiri. Pada siklus II tema yang dibahas adalah diri ku dengan sub tema makanan kesukaan ku. Alat dan bahan yang digunakan adalah gambar makanan kesukaan, lembar kerja dan puzzle angka 1-8. 
"Ceria"

Jurnal Program Studi Pendidikan Anak Usia Dini

Berdasarkan pengamatan yang dilakukan pada siklus II, terlihat sudah ada peningkatan dari cukup menjadi baik, pada saat proses kegiatan pembelajaran seperti menyebutkan urutan bilangan 1-8, membilang 1-8, dan merangkai puzzle himpunan konsep bilangan 1-8. 
"Ceria"

Jurnal Program Studi Pendidikan Anak Usia Dini

Tabel 2

Hasil Observasi Konsep Bilangan Anak Siklus II

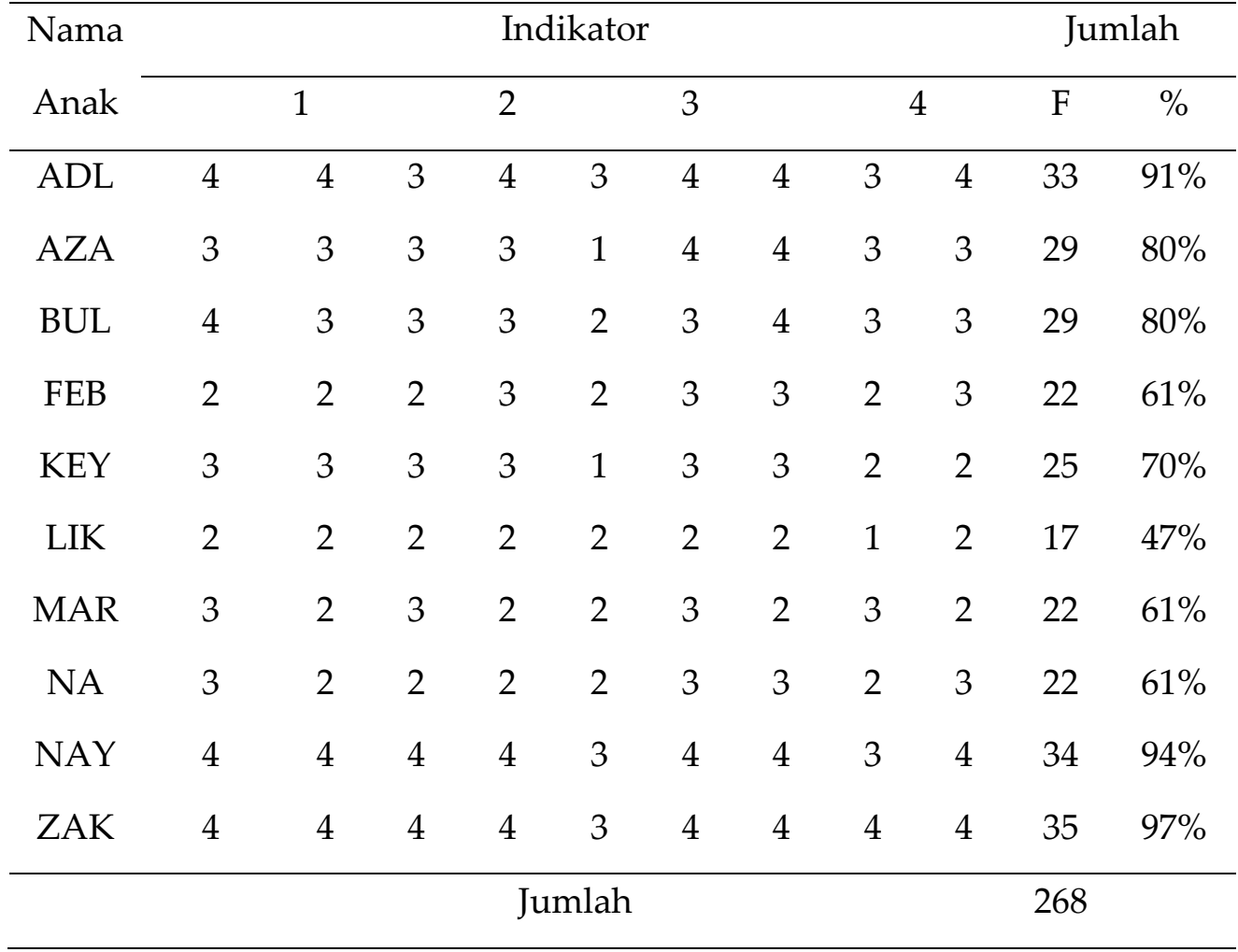

Hasil dari data pada tabel 2 diketahui bahwa pada siklus II diketahui bahwa kemampuan mengenal konsep bilangan pada siklus ini, terlihat bahwa kemampuan mengenal konsep bilangan anak telah meningkat dengan persentase peningkatan sebesar 50\%, yaitu dari 10 anak ada 5 anak yang skor kemampuan mengenal konsep bilangan telah mencapai indikator yang telah ditentukan.

Berdasarkan temuan di atas, peneliti kembali melakukan perbaikan pada siklus III agar dapat mencapai hasil yang lebih baik. Peneliti menambahkan variasi alat puzzle angka dan bahan yang lebih luas yaitu berupa kepingan puzzle angka yang semakin banyak dan sedikit rumit Pada siklus III tema yang dibahas adalah diriku dengan sub tema anggota keluarga ku. Alat dan bahan yang digunakan antara lain gambar anggota keluarga, lembar kerja dan puzzle angka 1-10.

Berdasarkan pengamatan yang dilakukan pada siklus III, terlihat adanya perbaikan baik hasil belajar maupun proses belajar, meningkatnya kemampuan 
"Ceria"

Jurnal Program Studi Pendidikan Anak Usia Dini

mengenal konsep bilangan dari baik menjadi sangat baik. Hal tersebut ditunjukkan dari persentase peningkatan yang ada. Selain itu, anak-anak dapat pengalaman baru bermain puzzle angka. Selain peningkatan dalam kemampuan mengenal konsep bilangan, melalui penelitian ini peneliti dapat mengetahui bahwa kegiatan praktek langsung yang dilakukan dapat juga mengembangkan aspek perkembangan yang lainnya. Kegiatan bermain puzzle angka adalah kegiatan yang tidak membosankan bagi anak. Bahkan anak-anak senang sekali ketika disuruh memilih macam-macam bentuk puzzle angka.

\section{Tabel 3}

Hasil Observasi Konsep Bilangan Anak Siklus III

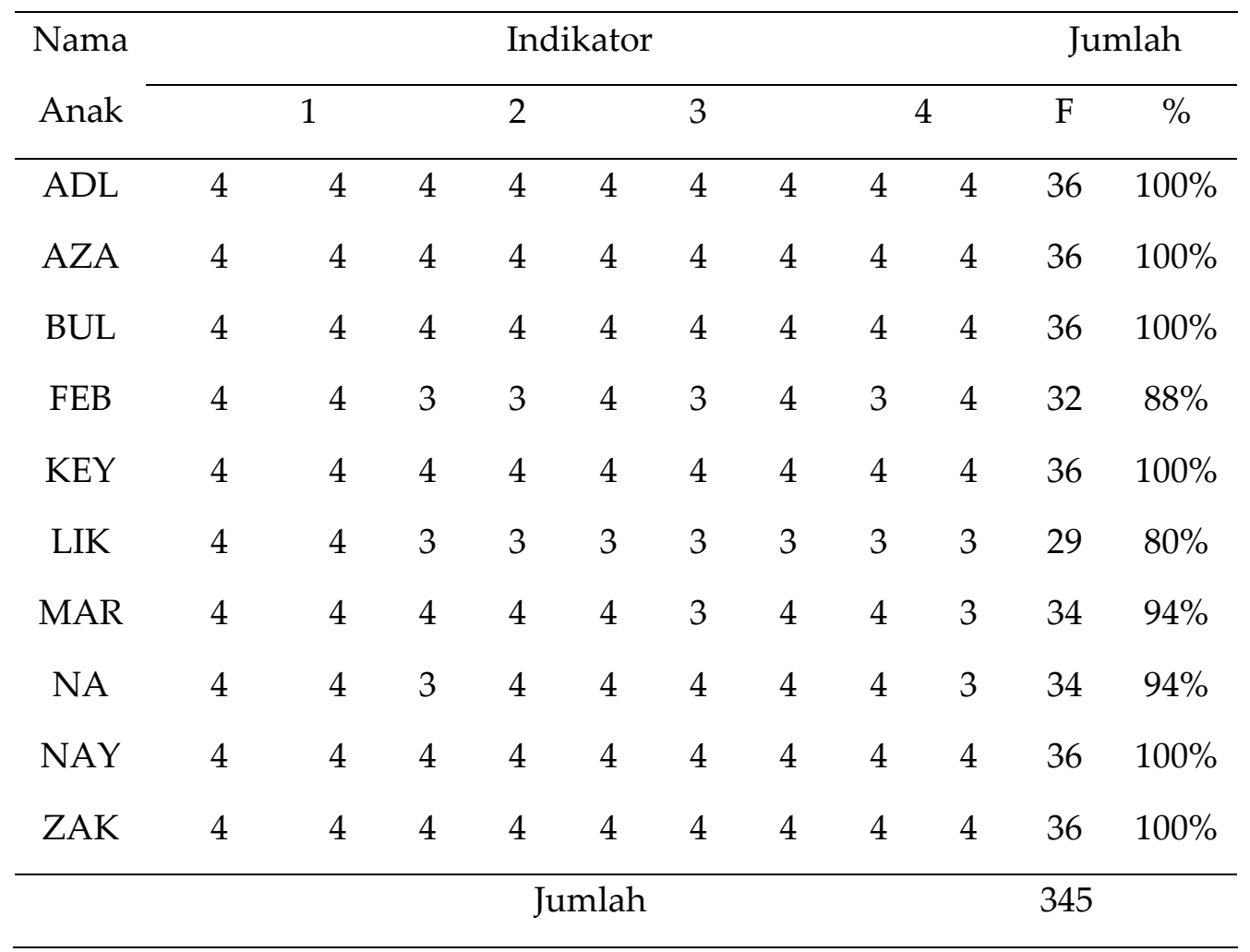

Hasil dari data pada tabel 3 diketahui bahwa kemampuan mengenal konsep bilangan pada siklus ini, terlihat bahwa kemampuan mengenal konsep bilangan anak telah meningkat dengan persentase peningkatan sebesar 100\%, yaitu dari 10 anak ada 10 anak yang skor kemampuan mengenal konsep bilangan telah 
"Ceria”

Jurnal Program Studi Pendidikan Anak Usia Dini

mencapai indikator yang telah ditentukan. Dengan adanya peningkatan pada indikator mengenal konsep bilangan tersebut, maka peneliti menganggap hasil dari siklus III ini telah sesuai dengan hipotesis yang diajukan.

Berdasarkan paparan hasil data terkait mengenal konsep bilangan anak di atas dapat diketahui bahwa bermain puzzle angka memberikan perkembangan menyebutkan urutan bilangan 1-10, Membilang (Mengenal konsep bilangan dengan benda-benda) 1-10, Merangkai puzzle himpunan 1-10, menulis konsep bilangan 1-10, Mencocokan bilangan dengan lambang bilangan 1-10, Mengurutkan bilangan dengan menggunakan puzzle angka 1-10, serta Membedakan dan membuat 2 kumpulan benda yang sama jumlahnya, yang tidak sama, lebih banyak dan lebih sedikit.

\section{Kesimpulan}

Berdasarkan hasil penelitian berkenaan dengan upaya meningkatkan kemampuan mengenal konsep bilangan melalui bermain puzzle angka pada anak usia 4-6 tahun di TK Sabela Kec. Pasar Kemis Kab. Tangerang, maka dapat diambil kesimpulan yaitu: (1) Dengan bermain puzzle angka dapat meningkatkan kemampuan mengenal konsep bilangan anak usia 4-6 tahun di TK Sabela Kec. Pasar Kemis Kab. Tangerang, hal ini ditunjukan dengan meningkatnya kemampuan mengenal konsep bilangan anak yang pada kondisi awal didapatkan data dengan presentase $30 \%$ menjadi $30 \%$ pada siklus I dan menjadi $50 \%$ pada siklus II dan meningkat lagi menjadi $100 \%$ pada siklus III sehingga besar presentase kenaikan antara dari kondisi awal ke Siklus I sebesar 30\%, dari Siklus I ke Siklus II sebesar 50\% dan dari Siklus II ke Siklus III sebesar 100\% 2. Kondisi pada saat pelaksanaan kegiatan belajar mengenal konsep bilangan dengan bermain puzzle angka, anak terlihat senang dan bersemangat sehingga mereka tidak jenuh dalam belajar mengenal konsep bilangan seperti menyebutkan urutan bilangan 1-10, membilang/ mengenal konsep bilangan 1-10, merangkai puzzle himpunan konsep bilangan 1-10. 
"Ceria"

\section{Jurnal Program Studi Pendidikan Anak Usia Dini}

Berdasarkan kesimpulan di atas, ada beberapa hal penting yang dapat ditindak lanjut antara lain bagi guru dan sekolah, dimana guru dalam melaksanakan KBM sebaiknya menggunakan berbagai macam metode pembelajaran yang sesuai dengan karakteristik anak, agar mampu mencapai tujuan pembelajaran dan ketuntasan belajar yang diharapkan; Bagi orang tua, sebaiknya lebih memperhatikan perkembangan dan potensi yang dimiliki oleh anak. Semua potensi yang dimiliki anak sebaiknya diberikan kesempatan juga untuk berkembang dengan baik, salah satunya adalah mengenal konsep bilangan, dan bagi peneliti selanjutnya diharapkan memperhatikan dan melengkapi instrumen yang digunakan untuk mengukur aspek-aspek kreativitas agar mendapatkan hasil yang maksimal.

\section{Daftar Acuan}

Afin Murtie, Ca Lis Tung (2013). Jakarta: PT Gramedia.

Arikunto, S., Suhardjono \& Supardi. (2015). Penelitian Tindakan Kelas. Jakarta: Bumi Aksara.

Direktorat Pendidikan Anak Usia Dini. (2010). Bahan dan Media Pembelajaran Kelompok Bermain:Pengembangan Konsep Pengetahuan Matematika. Jakarta : Kementrian Pendidikan Nasional.

Fatimah. (2009). Matematika Asyik Dengan Metode Permodelan. Bandung: Tarsito 2009.

Mulyasa, H. E. (2016). Praktik Penelitian Tindakan Kelas. Bandung: Remaja Rosdakarya.

Peraturan Menteri Pendidikan dan Kebudayaan Nomor 137 Tahun 2014 Tentang Standar Nasional Pendidikan Anak Usia Dini.

Susanto, Ahmad. (2011). Perkembangan Anak Usia Dini: Pengantar dalam Berbagai Aspeknya. Jakarta: Kencana Prenada Media Group

Yuli Astuti. (2016). Cara Mudah Asah Otak Anak. Yogyakarta. 